\title{
Physical Education Survey during the COVID-19 Pandemic in Eastern Indonesia
}

\author{
Rizky Nurulfa ${ }^{1, *}$, Christianti Anggraini Motto ${ }^{2}$, Firmansyah Dlis ${ }^{1}$, James Tangkudung ${ }^{1}$, \\ Johansyah Lubis ${ }^{1}$, Junaidi ${ }^{1}$
}

${ }^{1}$ Faculty of Sport Education, Universitas Negeri Jakarta, 13220, DKI Jakarta, Indonesia

${ }^{2}$ Faculty of Sport Education, Universitas Negeri Manado, 95618, Sulawesi Utara, Indonesia

Received September 22, 2020; Revised November 19, 2020; Accepted March 27, 2021

\section{Cite This Paper in the following Citation Styles}

(a): [1] Rizky Nurulfa, Christianti Anggraini Motto, Firmansyah Dlis, James Tangkudung, Johansyah Lubis, Junaidi , "Physical Education Survey during the COVID-19 Pandemic in Eastern Indonesia," International Journal of Human Movement and Sports Sciences, Vol. 9, No. 4, pp. 668 - 675, 2021. DOI: 10.13189/saj.2021.090410.

(b): Rizky Nurulfa, Christianti Anggraini Motto, Firmansyah Dlis, James Tangkudung, Johansyah Lubis, Junaidi (2021). Physical Education Survey during the COVID-19 Pandemic in Eastern Indonesia. International Journal of Human Movement and Sports Sciences, 9(4), 668 - 675. DOI: 10.13189/saj.2021.090410.

Copyright $@ 2021$ by authors, all rights reserved. Authors agree that this article remains permanently open access under the terms of the Creative Commons Attribution License 4.0 International License

\begin{abstract}
Almost the whole world was affected by the Study From Home (SFH) policy from Elementary Schools to Higher Education during the Covid-19 Pandemic. However, teaching and learning activities did not stop even though the world was facing an outbreak of this disease including Indonesia. Despite face-to-face teaching and learning activities since last March, schools are not ready to reopen face-to-face teaching and learning activities physically because it is still difficult to implement the Covid-19 prevention health protocol and increasingly massive procedures in educational institutions during face-to-face learning. This study aims to see how the distance learning activities for students are implemented in eastern Indonesia. A total of 432 students from junior high school, high school and tertiary education were sampled in this study. Through this research, data about interest in distance learning can be obtained, as well as what they experience during the distance learning period. This study also provides an overview of difficulties during distance learning, the dominant material and tasks given by the teacher during the Pandemic period as well as inhibiting and supporting factors in distance learning. This study uses a descriptive method, with the research instrument using a questionnaire made through the google form application from respondents and direct visits of subject teachers to students' homes that are not reached by the internet.
\end{abstract}

Keywords E-Learning, Physical Education, COVID-19, Eastern Indonesia, Students

\section{Introduction}

The World Health Organization announced that Covid-19 was a global pandemic on March 11, 2020 [1]. Covid-19 was declared to have entered Indonesia on March 2, 2020 after a dance instructor (31 years old) and her mother (64 years old) were tested positive for the corona virus from their relative who is a Japanese national who visited Indonesia in early February [2,3].

On April 9, 2020, Covid-19 has spread to 34 provinces in Indonesia [4]. Most governments around the world have temporarily closed educational institutions in an effort to reduce the spread of COVID-19 because education systems around the world have also been affected by the COVID-19 pandemic [5]. School closures are often used as a non-medical precaution to achieve this goal [6] and many peoples who have lost their relevance [7] also children can be a trigger for the spread of diseases resulting from high levels of association in school [8] for example a study of children and adolescents in the UK found that the average number of daily social contacts during school holidays are approximately $50 \%$ of school holidays $[9,10]$. National and international organizations recommend that the importance of maintaining distance or direct physical contact with other people [11], such as avoiding crowds in markets, places of worship, 
entertainment venues, schools, etc. [12-14].

UNESCO (United Nations Educational, Scientific and Cultural Organization) on 4 March 2020 recommended the use of distance learning and opened an educational platform that schools and teachers could use to reach students remotely and limit educational distractions [15]. This is also implemented by the Government. Indonesia in the circular letter of The Ministry of Education and Culture of The Directorate of Higher Education No. 4 of 2020 which is supported by circular letter No. 15 of 2020 concerning the Prevention of the Spread of Corona Virus (Covid-19) in Higher Education and Schools. Through this circular, the Ministry of Education and Culture provides instructions to universities and schools to conduct distance learning and advises students to study from their homes [16,17].

The handling of COVID-19 has detailed four levels of regional zoning criteria based on color, as an indicator of the risk category for COVID-19 as seen from the level of transmission or spread. Some of the criteria for this area range from risk areas: Green Zone (Not Affected), Yellow Zone (Low Risk), Orange Zone (Medium Risk), Red Zone (High Risk). However, according to the National Task Force for the Acceleration of Handling Covid-19, data on the spread of Covid-19 is very dynamic. Therefore, there are areas that may not have been affected previously, but can turn into low risk areas, as well as areas with low risk that can shift into moderate risk zones, or vice versa [18].

In this pandemic situation, well-known companies such as Google, Microsoft, Zoom and Slack have offered many features of their products to educational institutions that can be useful in online learning. Based on reports from the Microsoft team there has been a significant growth on March 10 where the application users are 750, increasing sharply to 13.8698 users on March 24 [19]. However, the implementation of e-learning is not always smooth and effective. Sometimes students feel that online learning is very boring or not very interesting because it takes time to learn to use modern technology applications and online learning is theoretical. Students want two-way interaction which sometimes gets difficult to implement. The learning process cannot reach its full potential until students practice what they learn. (Song et al in Dhawan, 2020). Based on research from Parker, there are poor results from online learning where there are many students who are still not ready to balance their work, family and social life with the application of online learning [21]. We know that the content in our Physical education program is important to help students deal with the stress of COVID-19. Many children experience stress during this pandemic. Physical education is the only subject that includes outcomes targeted at positive mental health; teach students about stigma, strategies to support mental health and positive resources and support for coping with mental health problems Physical education is the only subject that provides students with the opportunity to be physically active which is an important component of holistic health - physical activity is a valuable approach to supporting the mental health of youth [22]. Physical education differs from other subjects, in that its curriculum encourages opportunities to develop social and emotional skills such as communication, leadership, teamwork, self-awareness and self-management. "Physical education classes are one of the best contexts for developing social and emotional competence" [23].

Physical education centers on physical activity and is clearly distinct from general knowledge-based subjects. Therefore, online physical education classes require special preparation and operation to communicate and practice the values of physical education well. Currently, online classes are occurring in tandem around the world, there is a need to examine whether online physical education classes are being held and conveying the values of physical education appropriately [24]. The use of technology to guide people during physical education classes has become a great strategy for people who cannot leave their homes. Besides, technology can insert people in an immersive environment increasing their interaction, merriment, improving their immune and cardiovascular systems. Physical education teachers must be considered an essential health professional during this pandemic period because they can guide and stimulate individuals to practice physical exercise routinely, in order to keep and improve their health [25]. There are suggestions for Modifications to in-person P.E classes may include limiting the use of ball sharing, avoiding the combination of classes, and using activities that require no physical contact or students being in close proximity to each other [26] There are also many studies that say that the implementation of e-learning should be done in normal situations and as an option to improve the teaching process [27-30] Most of the studies conducted did not focus on physical education [30-32] which in its implementation is dominated by direct performance.

This research was conducted in several regions in Eastern Indonesia including: Papua (Jayapura), West Papua, East Nusa Tenggara (East Flores), Maluku (Ambon), Southeast Maluku (Ternate), Southeast Sulawesi, Central Sulawesi, South Sulawesi (Makassar), Gorontalo, North Sulawesi: Manado, Bitung, Minahasa, and several other areas such as the Sangihe Islands: Tahuna Siau, Tagulandang, Biaro, and Talaud [33]. This study aim explores students perceptions of e- learning as the impact of schooling from home during the COVID-19 Pandemic in Indonesia. Described how the implementation of distance learning activities for students in eastern Indonesia, such as; their interest in carrying outdistance learning; the used teacher's methods, and they experience during the distance learning period. Hopefully, this research can add valuable insights into the e-learning literature and provide advice to improve the practice of e-learning; in its application in physical education. 


\section{Literature Review}

\subsection{Distance Learning}

Distance education has been applied for a long time, which is nearly 300 years [34]. More say "Distance learning is learning aimed at those who are geographically distant" [35]. Distance education is learning using one or more technological media and tools in delivering instructions to students as support for regular and substantive interactions or synchronous and asynchronous instructions [36]. Distance learning is more focused on one's abilities related to distance, time and place, then distance learning develops into online learning using web-based technology, etc. (Keegan; Guilar; Conrad; Nichols in Clark, 2019 [34] ).

\subsection{E-Learning}

Various kinds of meanings of the term e-learning [35]. $\mathrm{E}$ learning is a formal teaching system in electronic form using the internet network as a means of delivering information, in a simple sense e-learning is also called online learning, which is learning that is carried out online without being bound by certain times and places is more focused on technology and communication integration [37-39].

\subsection{Physical Education}

Physical education is one of the subjects in schools which is a driving medium for the development of motor skills, physical abilities, knowledge, sportsmanship, habituation of healthy living patterns and character building (mental, emotional, spiritual and social) in order to achieve the goals of the National education system. Physical education is a subject given at a particular school level which is one part of overall education that prioritizes physical activity and fostering a healthy life for growth and development of physically, mentally, socially and emotionally that is harmonious, harmonious and balanced [40]. Physical education is an educational process that utilizes physical activities that are planned systematically aimed at developing and improving individuals organically, neumuscularly, perceptually, cognitively, and emotionally, within the framework of the national education system [41,42]. Physical education can also be a source of research on several theories of motivation. Among them are competence, expected value, social cognitive achievement goals, attribution, achievement of needs and determination of fate [43].

\subsection{Barrier and Challenges in Online Learning}

The findings from this study are in line with the barriers that have been previously documented in the literature, which include intrinsic and extrinsic barriers as well as institutional inhibitors to online teaching. The factors identified in this study map onto the conceptual framework of perceived barriers to online education developed by specifically, the institutional barriers, training and technology barriers, interpersonal barriers, and cost/benefit barriers map onto the following Muilenburg and Berge barrier categories, respectively: administrative structure, organizational change, and legal issues; technical expertise, support, and infrastructure; social interaction and program quality; and faculty time and compensation (Haber \& Mills; (Maguere; Muilenburg and Berge in Lioyed et al [44]. However, this study also offers a number of novel and important contributions to the literature.

\section{Materials and Methods}

The survey was conducted from June 11 to July 2, 2020. In this study, a quantitative approach was followed using a cross-sectional questionnaire. Quantitative methods are considered capable of providing reliable, valid, objective and generalizable findings. Moreover, questionnaires, one of most widely used quantitative instruments, may be administered to a large number of participants. If the researcher collects data based on a representative sample of the population, generalisations can be made about the whole population. The Questions consist of two types of closed questions on the Guttman scale as well as open questions with more thoughts and more than simple one-word answers. $r$ [45].

\section{Participants}

Random sampling was employed in this study. The sample consisted of 432 participants (184 male and 248 female) who were from secondary school, high school and university. Collected data was online questionnaire through google form for 277 participants and for those who didn't reach, the researcher sent the questioner to their teachers about 155 participants, while the teachers might print out the quiz and visit their students. The questionnaire was open for three weeks.

Table 1. Demography

\begin{tabular}{|c|c|c|}
\hline Age & N & Percentage (\%) \\
\hline $14-16$ & 328 & 75.93 \\
\hline $18-19$ & 70 & 16.20 \\
\hline $20-22$ & 37 & 7.87 \\
\hline & 432 & 100 \\
\hline
\end{tabular}

Table 2. Education background of participant

\begin{tabular}{|c|c|c|}
\hline Education & N & Percentage (\%) \\
\hline Secondary School & 159 & 36.81 \\
\hline High School & 234 & 54.17 \\
\hline University & 39 & 9.01 \\
\hline
\end{tabular}

Respondents are dominated by high-school students by $54.17 \%$ 
Table 3. Gender

\begin{tabular}{|c|c|c|}
\hline Male & 184 & 42.59 \\
\hline Female & 248 & 57.41 \\
\hline
\end{tabular}

Table 4. Living area of participant

\begin{tabular}{|c|c|c|}
\hline Province & N & Percentage (\%) \\
\hline Gorontalo & 22 & 5.1 \\
\hline NTT & 10 & 2.3 \\
\hline Maluku & 128 & 29.6 \\
\hline Maluku Utara & 16 & 3.7 \\
\hline Papua & 12 & 2.8 \\
\hline Papua Barat & 331 & 7.6 \\
\hline Sulawesi Barat & 11 & 2.5 \\
\hline Sulawesi Tengah & 14 & 3.2 \\
\hline Sulawesi Selatan & 8 & 1.9 \\
\hline Sulawesi Utara & 153 & 35.4 \\
\hline Sulawesi Tenggara & 25 & 5.8 \\
\hline
\end{tabular}

Table 5. Types of application tools prefer to use for e-learning

\begin{tabular}{|c|c|c|}
\hline PLATFORM & N & Percentage (\%) \\
\hline Facebook & 8 & 1.85 \\
\hline Google Classroom & 75 & 17.36 \\
\hline Google Meet & 26 & 6.02 \\
\hline Microsoft Teams & 15 & 3.47 \\
\hline Telegram & 7 & 1.62 \\
\hline Whatsapp & 41 & 9.49 \\
\hline Zoom & 102 & 23.61 \\
\hline
\end{tabular}

The dominant platform used is the media zoom of $23.61 \%$ and google classroom $17.36 \%$, while those who are outside the reach of the internet, the teacher comes to the student place, usually like a group consisting of 5-6 person in the same area, or parents come to the teacher to ask for their children's work.

Table 6. Perspective

\begin{tabular}{|c|c|c|c|}
\hline Questions & $\mathrm{N}$ & Yes & No \\
\hline I have sufficient internet quota during online learning & 432 & 31.48 & 68.52 \\
\hline I have facilities that support online learning & 432 & 32.64 & 67.36 \\
\hline The area where I live has a stable internet connection & 432 & 40.28 & 59.72 \\
\hline In my school/ college, we doing online learning & 432 & 68.06 & 31.94 \\
\hline I have exercise equipment at home (such as a bicycle, dumble, cones, balls, etc.) & 432 & 48.84 & 51.16 \\
\hline I have difficulty learning concentration during online learning & 432 & 30.79 & 69.21 \\
\hline I feel dizzy when staring at my laptop/computer or cellphone for a long time & 432 & 34.03 & 65.97 \\
\hline I have limited self in online learning & 432 & 33.56 & 66.44 \\
\hline I have problems in the process of using online learning applications & 432 & 28.01 & 71.99 \\
\hline $\begin{array}{c}\text { Communication through applications in online learning during this pandemic is good } \\
\text { enough }\end{array}$ & 432 & 52.08 & 47.92 \\
\hline I feel enthusiastic about online learning & 432 & 66.90 & 33.10 \\
\hline By online learning, I can still interact with friends and teachers & 432 & 64.35 & 35.65 \\
\hline Online learning media is more diverse and interesting & 432 & 75.93 & 24.07 \\
\hline I think I must have the ability in the field of technology to support learning abilities & 432 & 63.19 & 36.81 \\
\hline During study from home, I felt closer to my family & 432 & 90.51 & 9.49 \\
\hline Through online learning, I can be more creative & 432 & 79.63 & 20.37 \\
\hline Study time during online learning is more flexible than face to face & 432 & 90.05 & 9.95 \\
\hline I easily understand the material given by the teacher during the online learning & 432 & 45.14 & 54.86 \\
\hline I think that I can complete the assignment given by the teacher & 432 & 45.14 & 54.86 \\
\hline I think the instructions for giving assignments online are pretty clear & 432 & 2.06 & 78.94 \\
\hline $\begin{array}{l}\text { I like learning with direct examples, /movements or instructions given by the teacher } \\
\text { directly }\end{array}$ & 432 & 90.29 & 9.72 \\
\hline I love learning by voice recording or explanation via audio & 432 & 54.63 & 45.37 \\
\hline I think the time to collect the duties is sufficient & 432 & 29.17 & 70.83 \\
\hline $\begin{array}{c}\text { The Physical Education / Sports teacher explains the material entirely on online } \\
\text { learning/distance learning }\end{array}$ & 432 & 43.29 & 56.71 \\
\hline I still can do physical activity/exercise while at home during the Covid-19 pandemic & 432 & 80.09 & 19.91 \\
\hline I think online learning is more accessible than face-to-face learning? & 432 & 24.77 & 75.23 \\
\hline I believe practical subject is not suitable for online & 432 & 93.98 & 6.02 \\
\hline
\end{tabular}


From the data above, in terms of $68.06 \%$ school or university conducting online learning, it can be concluded that students in eastern Indonesia experience difficulties in carrying out distance learning including $68.52 \%$ did not have money to buy an internet quota, $67.36 \%$ did not have adequate facilities for distance learning, 59.72\% experienced difficulties because the internet network was often interrupted. In terms of supporting physical education learning through online learning, as many as $71.99 \%$ experienced difficulties in accessing the applications used, $51.16 \%$ of students in eastern Indonesia did not have sports equipment such as bicycles, dumble, cones, balls, etc.).

The exciting things obtained from online physical education lessons are: as many as $66.90 \%$ of students are enthusiastic about online learning, $75.92 \%$ are interested because the learning media used are varied, $64.35 \%$ feel that they can interact with friends or teachers with online learning. $79.63 \%$ think that with online learning they can be creative. In terms of students' limitations during physical education online learning, 33.66\% felt they had limited self, $30.79 \%$ felt unable to concentrate, and $34.03 \%$ felt dizzy when staring at a laptop/computer or cellphone for a long time. Another positive value obtained by students in this online learning is that $90.51 \%$ feel closer to their family, $63.19 \%$ feel they must have the ability to support learning abilities.

Table 7. Physical education lessons during study at home

\begin{tabular}{|c|c|c|}
\hline $\begin{array}{c}\text { Physical Education Lessons During Study at } \\
\text { Home }\end{array}$ & N & $\begin{array}{c}\text { Percentage } \\
\text { (\%) }\end{array}$ \\
\hline Track and field:sprint and running & 13 & 3.01 \\
\hline Sports analysis application system & 26 & 6.02 \\
\hline Health related fitness & 46 & 10.65 \\
\hline Big ball games, such as Basketball, volleyball & 180 & 41.67 \\
\hline Any small ball games & 161 & 3.70 \\
\hline Soccer (theory and practical) & 117 & 27.08 \\
\hline Theory of swimming & 10 & 2.31 \\
\hline Theory of gymnastics & 24 & 5.56 \\
\hline
\end{tabular}

The sport that is often a favorite of students in eastern Indonesia is a game with group characteristics. It can be seen from the data that $41.67 \%$ of the material taught by teachers in physical education during the Covid-19 pandemic is big ball games such as volleyball, basketball and etc. Soccer has even become one of the most widely taught materials as many as $27.08 \%$ of children learned this during the pandemic.

Table 8. Kinds of a task by PE teacher during the online learning

\begin{tabular}{|c|c|c|}
\hline $\begin{array}{c}\text { Kinds of a task by PE teacher during } \\
\text { the online learning }\end{array}$ & $\mathrm{N}$ & Percentage (\%) \\
\hline $\begin{array}{c}\text { Tasks about motion in sports can be in } \\
\text { the form of pictures, photos or videos }\end{array}$ & 171 & 39.58 \\
\hline Questionnaire & 32 & 7.41 \\
\hline Resume/ Paper & 196 & 45.37 \\
\hline Other & 33 & 7.64 \\
\hline
\end{tabular}

Table 9. Teaching resources from the teacher during the pandemic

\begin{tabular}{|c|c|c|}
\hline $\begin{array}{c}\text { Teaching resources from the } \\
\text { teacher during the pandemic }\end{array}$ & $\mathrm{N}$ & Percentage (\%) \\
\hline Online Discussion & 76 & 11.81 \\
\hline Website links & 45 & 12.96 \\
\hline Youtube links & 79 & 1.39 \\
\hline Module/task sheet & 147 & 34.03 \\
\hline Video-Based Learning & 51 & 34.49 \\
\hline No clues & 33 & 5.32 \\
\hline
\end{tabular}

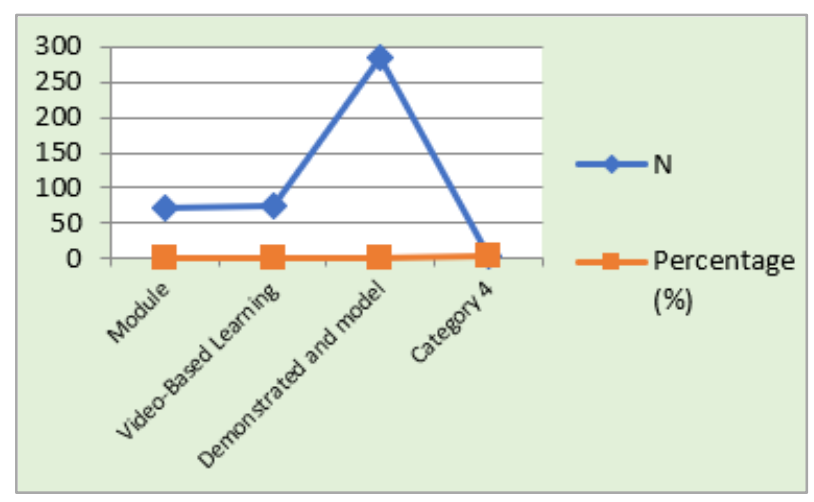

Figure 1. Kinds of a task by PE teacher in normal situations

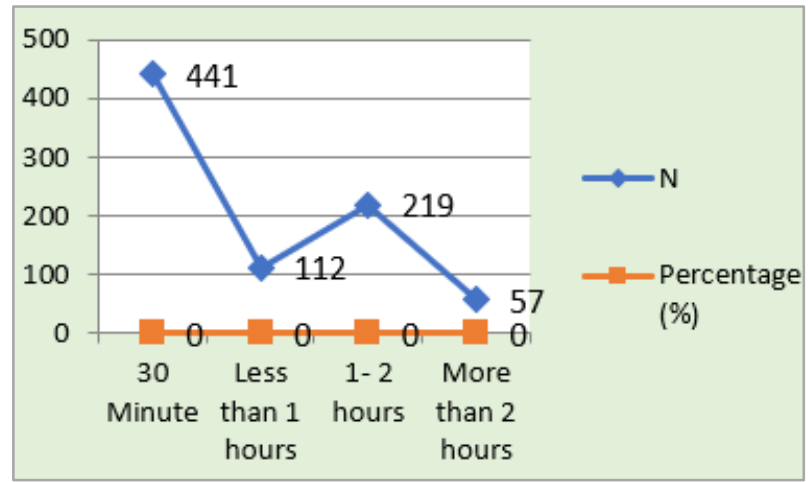

Figure 2. Time allocation for PE a week in normal situation

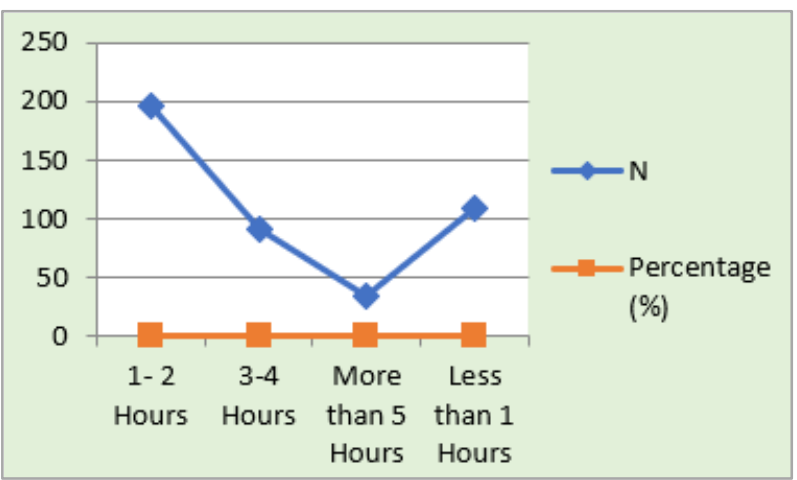

Figure 3. Screen time before the pandemics 


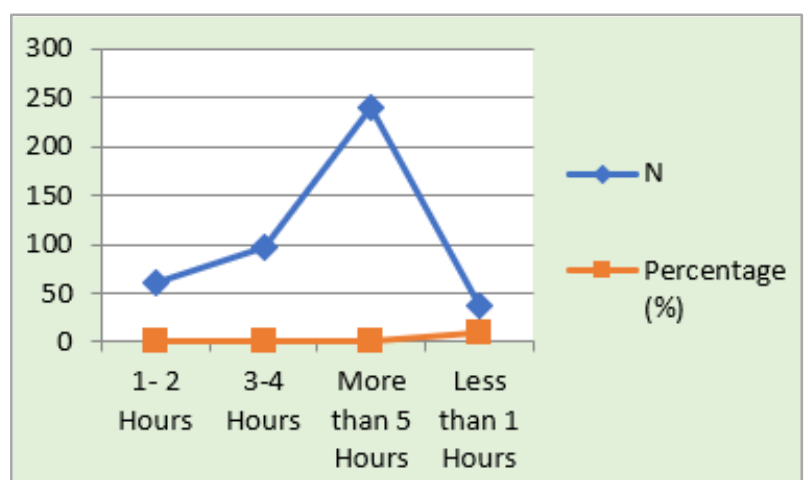

Figure 4. Screen time during the pandemics

\section{Discussion}

The findings of this study have implications not only for Indonesia but also for other experienced developing countries. These findings indicate that students are not ready for the application of e-learning due to a lack of understanding of knowledge about the operation of e-learning applications due to the absence of access to the internet network and there are still many students who are less fortunate in terms of economics [46-50]. Students prefer to study directly in the classroom because for them learning together is more fun than studying at home without friends.

\section{Conclusion}

This survey shows the constraints and challenges as well as problems for students in eastern Indonesia, especially those living in archipelagic areas and far from the city center due to the lack of technological touch in the areas where they live. These findings indicate an important point that distance learning for students in eastern Indonesia is at the top of the application barrier, which is evidenced by the fact that students do not have adequate knowledge and skills in using e-learning applications. In addition, most students also agreed that there was no access to the device and a good internet connection. This survey shows that policymakers, particularly schools, must develop comprehensive strategies that prepare students to use e-learning. Nevertheless, the findings of this study can serve as an alert to teachers, schools, and policymakers about the barriers to using e-learning in this difficult time.

\section{Acknowledgements}

We would like to thank all participants involved in this study.

\section{REFERENCES}

[1] WHO. WHO Director-General's opening remarks at the media briefing on COVID-19 - 11 March 20202020. https://www.who.int/dg/speeches/detail/who-director-gener al-s-opening-remarks-at-the-media-briefing-on-covid-19--11-march-2020 (accessed August 7, 2020).

[2] Ratcliffe R. First coronavirus cases confirmed in Indonesia amid fears nation is ill-prepared for outbreak. WwwTheguardianCom 2020.https://www.theguardian.com /world/2020/mar/02/first-coronavirus-cases-confirmed-in-in donesia-amid-fears-nation-is-ill-prepared-for-outbreak.

[3] bangkokpost.com. Indonesia confirms first cases of coronavirus. Bangkok Post 2020. https://www.bangkokpost .com/world/1869789/indonesia-confirms-first-cases-of-coro navirus (accessed August 8, 2020).

[4] Andriyanto H. Indonesia's Covid-19 Recoveries Beat Active Cases for First Time. Jakarta Globe 2020. https://jakartaglobe.id/news/indonesias-covid19-recoveriesbeat-active-cases-for-first-time (accessed August 8, 2020).

[5] UNESCO. COVID-19 educational disruption and response: Continuation of radio education for secondary level students in Nepal.Https://EnUnescoOrg/News/Covid-19-Educationa l-Disruption-and-Response-Continuation-Radio-EducationSecondary-Level 2020. https://doi.org/17/06/2020.

[6] Jackson C, Vynnycky E, Hawker J, Olowokure B, Mangtani P. School closures and influenza: Systematic review of epidemiological studies. BMJ Open 2013. https://doi.org/10 .1136/bmjopen-2012-002149.

[7] Li C. The COVID-19 pandemic has changed education forever. This is how. World Econ Forum 2020. https://www.weforum.org/agenda/2020/04/coronavirus-edu cation-global-covid19-online-digital-learning/ (accessed August 7, 2020).

[8] Mossong J, Hens N, Jit M, Beutels P, Auranen K, Mikolajczyk R, et al. Social contacts and mixing patterns relevant to the spread of infectious diseases. PLoS Med 2008. https://doi.org/10.1371/journal.pmed.0050074.

[9] Jackson C, Vynnycky E, Mangtani P. The Relationship between School Holidays and Transmission of Influenza in England and Wales. Am J Epidemiol 2016. https://doi.org/10.1093/aje/kww083.

[10] Eames KTD, Tilston NL, White PJ, Adams E, Edmunds WJ. The impact of illness and the impact of school closure on social contact patterns. Health Technol Assess (Rockv) 2010. https://doi.org/10.3310/hta14340-04.

[11] Dalton CB, Corbett SJ, Katelaris AL. COVID-19: implementing sustainable low cost physical distancing and enhanced hygiene. Med J Aust 2020. https://doi.org/10.569 4/mja2.50602.

[12] Chen N, Zhou M, Dong X, Qu J, Gong F, Han Y, et al. Epidemiological and clinical characteristics of 99 cases of 2019 novel coronavirus pneumonia in Wuhan, China: a descriptive study. Lancet 2020. https://doi.org/10.1016/S01 40-6736(20)30211-7.

[13] Miller MJ, Loaiza JR, Takyar A, Gilman RH. COVID-19 in Latin America: Novel transmission dynamics for a global pandemic? PLoS Negl Trop Dis 2020;14:e0008265. 
[14] Yang Y, Li W, Zhang Q, Zhang L, Cheung T, Xiang Y-T. Mental health services for older adults in China during the COVID-19 outbreak. The Lancet Psychiatry 2020;7:e19. https://doi.org/https://doi.org/10.1016/S2215-0366(20)3007 9-1.

[15] UNESCO. 290 million students out of school due to COVID-19: UNESCO releases first global numbers and mobilizes response 2020. https://en.unesco.org/news/290-m illion-students-out-school-due-covid-19-unesco-releases-fir st-global-numbers-and-mobilizes (accessed August 7, 2020).

[16] Https://pusdiklat.kemdikbud.go.id/. SURAT EDARAN MENDIKBUD NO 4 TAHUN 2020 TENTANG PELAKSANAAN KEBIJAKAN PENDIDIKAN DALAM MASA DARURAT PENYEBARAN CORONA VIRUS DISEASE (COVID- 1 9) - Pusdiklat Pegawai Kementerian Pendidikan dan Kebudayaan. Https://PusdiklatKemdikbudG oId/ 2020.

[17] Kemendikbud. Surat Edaran Sekretaris Jenderal No.15 Tahun 2020 2020. file:///C:/Users/asus/Downloads/INFOG RAFIS_BDR_SE_SESJEN

KEMENDIKBUD_15_2020_FINAL.pdf (accessed August 7, 2020).

[18] Syamsul A. Inilah pembagian zona wilayah penyebaran corona berdasarkan risiko. Kontan 2020. https://nasional.kontan.co.id/news/inilah-pembagian-zonawilayah-penyebaran-corona-berdasarkan-risiko (accessed August 6, 2020).

[19] Soni VD. Global Impact of E-learning during COVID 19. Available SSRN 3630073 2020. https://doi.org/https://dx.do i.org/10.2139/ssrn.3630073.

[20] Dhawan S. Online Learning: A Panacea in the Time of COVID-19 Crisis. J Educ Technol Syst 2020. https://doi.org/10.1177/0047239520934018.

[21] Parkes M, Stein S, Reading C. Student preparedness for university e-learning environments. Internet High Educ 2015. https://doi.org/10.1016/j.iheduc.2014.10.002.

[22] Halliday AJ, Kern ML, Garrett DK, Turnbull DA. The student voice in well-being: A case study of participatory action research in positive education. Educ Action Res 2019;27:173-96.

[23] Ciotto CM, Gagnon AG. Promoting social and emotional learning in physical education. J Phys Educ Recreat Danc 2018;89:27-33.

[24] Jeong H-C, So W-Y. Difficulties of Online Physical Education Classes in Middle and High School and an Efficient Operation Plan to Address Them. Int J Environ Res Public Health 2020;17:7279.

[25] Silva-Filho E, Teixeira ALS, Xavier JR da S, Braz Júnior D da S, Barbosa RA, Albuquerque JA de. Physical education role during coronavirus disease 2019 (COVID-19) pandemic Physical education and COVID-19. Mot Rev Educ Física 2020;26.

[26] Heidorn B. Preparing the next generation of physical education teachers. J Phys Educ Recreat Danc 2014;85:6-9.

[27] Hadijah S, Shalawati S. INVESTIGATING TEACHERS'BARRIERS TO ICT (INFORMATION COMMUNICATION TECHNOLOGYO INTEGRATION
IN TEACHING ENGLISH AT SENIOR HIGH SCHOOLS IN PEKANBARU. Proc ISELT FBS Univ Negeri Padang 2017;5:302-10.

[28] Juliane C, Arman AA, Sastramihardja HS, Supriana I. Digital Teaching Learning for Digital Native; Tantangan dan Peluang. J Ilm Rekayasa Dan Manaj Sist Inf 2017;3:29-35.

[29] Naveed QN, Muhammed A, Sanober S, Qureshi MRN, Shah A. Barriers effecting successful implementation of E-learning in Saudi Arabian Universities. Int J Emerg Technol Learn 2017. https://doi.org/10.3991/ijet.v12i06.70 03.

[30] Assareh A, Hosseini Bidokht M. Barriers to E-teaching and E-learning. Procedia Comput. Sci., 2011. https://doi.org/10. 1016/j.procs.2010.12.129.

[31] Astri LY. Barrier factors that influence satisfaction of E-learning: A literature study. Adv Sci Lett 2017. https://doi.org/10.1166/asl.2017.9007.

[32] Kabilan MK, Khan MA. Assessing pre-service English language teachers' learning using e-portfolios: Benefits, challenges and competencies gained. Comput Educ 2012. https://doi.org/10.1016/j.compedu.2011.11.011.

[33] Indonesia T. Definisi Indonesia Timur. Indones Timur 2020.

[34] Clark JT. Distance education. Clin. Eng. Handbook, Second Ed., 2019. https://doi.org/10.1016/B978-0-12-813467-2.000 63-8.

[35] Moore JL, Dickson-Deane C, Galyen K. E-Learning, online learning, and distance learning environments: Are they the same? Internet High Educ 2011. https://doi.org/10.1016/j.ih educ.2010.10.001.

[36] Seaman J, Allen IE, Seaman J. Grade increase: Tracking distance education in the United States. Babson Surv Res Gr 2018.

[37] Times TE. Definition of E-learning 2020.

[38] J AD. What is E-Learning? Defining what is e-learning is not as easy as it might first appear. E-Student 2020.

[39] Stoffregen J, Pawlowski JM, Pirkkalainen H. A Barrier Framework for open E-Learning in public administrations. Comput Human Behav 2015. https://doi.org/10.1016/j.chb. 2014.12.024.

[40] Depdiknas. Kurikulum Tingkat Satuan untuk Sekolah Dasar. Dikdasmen; 2006.

[41] Rosdiani D. Model pembelajaran langsung dalam pendidikan jasmani dan kesehatan. Bandung Alf 2012.

[42] Mulyanto. Belajar dan Pembelajaran Pejas. Bandung: Respati; 2016.

[43] Van den Berghe L, Vansteenkiste M, Cardon G, Kirk D, Haerens L. Research on self-determination in physical education: Key findings and proposals for future research. Phys Educ Sport Pedagog 2014. https://doi.org/10.1080/174 08989.2012.732563.

[44] LIoyd S a, Byrne MM, Mccoy TS. Faculty-Perceived Barriers of Online Education. J Online Learn Teach 2012.

[45] Fraenkel JR, Wallen NE, Hyun HH. Validity and reliability, how to design and evaluate research in science education 2011. 
[46] Jalli N. Lack of internet access in Southeast Asia poses challenges for students to study online amid COVID-19 pandemic. 17 Maret 2020. https://theconversation.com/lack -of-internet-access-in-southeast-asia-poses-challenges-for-st udents-to-study-online-amid-covid-19-pandemic-133787 (accessed November 9, 2020).

[47] Naresh B, Reddy BS. Challenges and opportunity of E-learning in developed and developing countries-a review. Int J Emerg Res Manag \&Technology 2015;4:259-62.

[48] Subedi S, Nayaju S, Subedi S, Shah SK, Shah JM. Impact of
E-learning during COVID-19 pandemic among nursing students and teachers of Nepal. Internafional J Sci Healthc Res 2020:68-76.

[49] Zaharah Z, Kirilova GI. Impact of Corona Virus Outbreak Towards Teaching and Learning Activities in Indonesia. SALAM J Sos Dan Budaya Syar-I 2020. https://doi.org/10.15408/sjsbs.v7i3.15104.

[50] MANISH T. Education under lockdown. 26 April 2020. https://www.recordnepal.com/category-explainers/educatio n-under-lockdown/ (accessed November 9, 2020). 